留談会編集委員会（編集委員長：徳田耕一）に上る慎重な番，また必要な場 合は著者による修正の後，技術・教育論文集として出版し，大会当日頒布して いる。

対象論文は, 電気化学, 工業物理化学, 電子材料等, 本協会関連分野 0 技術, 教育に関する研究で, 大学, 高専に加えて企業からの参加が増加していること は喜ばしいことである。発表論文は技術諭文と教育論文に大别できるが，平成 5 年春李大会では, 発表件数も 20 件を超え，招待講演等を加えシンポジウムは 2 日間にわたって開催される。

本準談会のもう一つの活動は, 教師, 技術者ならびに学生・生徒を対象とし た当該分野の技術・教育比関する研究会，セミナー，講習会の開催でむる。平 成 4 年度は, 本会普及委員会との共催により，8月24〜26日の3日間にわたり， 青山学院大学総合研究所ビル化学実験室ならびに横浜国立大学工学部理学実験 棟において，“初学者のための実習電気化学セミナ一”を催した。本協会関連分 野のための基礎教育の理念・方法に関する検討もこれから進めていく予定であ る。また，青少年の理工学離れが叫ばれている今日，若年層を対象とした科学 技術啓蒙活動は，今後本懇談会の活動の重要な部分を占めることになると思わ れる。

(春山 志郎)

\title{
17. エネルギー会議・SOFC 研究会
}

\section{1 設 立}

燐酸型燃料電池, 溶融炭酸塩型燃料電池は, 1980 年代前半には主でに国のム ーンライト計画で取り上げられ研究開発が進められていたが，固体電解質型燃 料電池に関する研究開発㹥当時, 民間会社の主導で進められていた。昭和 61 年 (1986 年)には, 山本 治氏（三重大）がSOFCの研究開発を推進するために研 究会の必要性と意晹を感じ，田川博章氏（横浜国大）とSOFC 研究会設立につ いて意見を交換し, 設立準備を始めた。この計画には, さらに土器屋正之氏(化 
学技術研究所 (現物質工学工業技術研究所)), 览玉晧雄氏（大阪工業技術試験 所）が参画し，さらに笛木和雄氏（東大）の協力を得て，研究会設立の具体的 な準備を行った。昭和 62 年度には，通産省工業技術院が石炭ガス利用の燃料電 池として MCFC 以外に SOFCも課題として加えられ，検討作業が行われたこ ともSOFC 研究会の設立に効果があった。昭和 63 年初頭に設立が決まったが， 電気化学協会には燃料電池研究留談会があることから, SOFC 研究会はエネル ギー会議の中に置かれることになった。燃料電池は電気化学的エネルギー変換 器であるが，SOFCの開発には，特に高温で使用するセラミック材料の研究開 発が重要な役割を果たすために，従来の燃料電池に対する発想法の延長では取 り扱うことができないために，あえて SOFC 研究会を別組織で設立することに した。

研究会設立の趣旨を趣意書からの抜粋で次に示す。

化石燃料，あるいは他のエネルギー源から作られる水素などの化学 エネルギーを高いエネルギー効率のもとに，直接，電気エネルギーに 変換するために，いままでに各種の燃料電池が研究されてきている。 固体電解質型燃料電池は，変換効率の高さ，操業性の良さ等の観点か ら大きな期待が寄せられているが，作動温度が高く，材料の両立性， 耐久性, 熱膨張率など，化学的・熱機械的性質に問題があるため，シ ステムとしては今までに Westinghouse 社の方式が具体化されている に過ぎない。固体電解質型燃料電池をシステムとして完成，実現する ために，固体電解質，電極材料などの構成材料の化学的・電子的性質， 各種材料間の両立性, 熱膨張率に代表される熱機械的性質の改良・改 善, 電極の作動機構の解明, システムとしての電池の構成法の検討な ぞの諸問題について, 解決を必要とする。このため, 広い分野から固 体電解質型燃料電池に関心のある研究者 - 技術者, 特に直接, 間接に 研究開発に従事している研究者・技術者が，研究成果，あるいは研究 開発上必要な各種情報を持ち寄り，具体的，汃詳細に立ち入った討 
論のできる全国的な研究連絡機関があることが望ましく，また，かよ うな活動組織の結成を望む声も強い。そこで，この要望に応える目的 を持って, 新しい研究烈談会組織, SOFC 研究会を電気化学協会エネ ルギー会議内に設立する。

わが国の研究開発の状況は, 基礎的研究は主として大学, 国立研究所（電総 研, 物質研) において固体電気化学, セラミックスなどの研究者によって行わ れている。ムーンライト計画では, 要素技術の研究 (平成 $1 \sim 3$ 年度) が終了 し, 平成 4 年度から次の 6 年計画が始まった。10 kW 級 SOFC の開発を目標と するが，要素技術，システム研究も並行して進められる。独自に研究開発を進 めている民間企業の数も多く, 開発の歴史も古い。SOFC の研究開発は，出発 物質の製造法から，セラミックス要素の製造・焼結法，スタック技術，システ ム化までを含め，どちらかというと民間企業の主導で進められている。

諸外国の状況は，アメリカでは Westinghouse 社が基礎研究から開発までを 含めて世界的に最も高い水準にある。1987 年に製作された $3 \mathrm{~kW}$ の発電装置は 4000 時間以上の運転が行われ，さらに規模の大さい $20 \mathrm{~kW}$ 発電装置が平成 3 年に 1700 時間，翌 4 年春にはわが国の民間企業との共同開発によって $25 \mathrm{~kW}$ 装置 (実能力は $40 \mathrm{~kW}$ ) が 1500 時間運転された。ヨーロッパでは，ヨーロッパ 共同体が中心となって平板型 SOFC の開発を目標として昭和 62 年に研究開発 チームが組織された。イギリス，オランダ，ノルウェー，デンマーク，フラン ス, スイスなどの大学, 国立研究所が基礎研究を, ドイツの Siemens 社, Dornier 社などの民間企業が発電装置を担当している。1〜2 $\mathrm{kW}$ 発電装置の開発が当 面の目標である。

\section{2 活 動}

第 1 回（1988 年）から第 20 回（1993 年）まで毎回テーマを設定し研究会を 行ってきている。

また，国際会議を開催している。第 7 回固体イオニクス国際会議 (SSI 7,1989 年秋, 箱根)のポスト会議として, “固体電解質型燃料電池シンポジウム’ 89 名 
古屋”（1989 年11月 13,14 日）を開催した。講演 31 件（国内 17，国外 14）。 第 1 回 SOFC 国際シンボジウム(1989 年 10 月, フロリダ); Shinghal, 山本 治，田川博章氏が協議を行い，シンポジウムの継続的開催と，アメリカ，ヨー ロッパ，日本に扔いて持古回り的纪開催することを決めた。第 2 回 SOFC 国際 シンポジウム（1991年7月 2〜5日，アテネ）：主催：ヨーロッパ共同体 (CEC), 共催: SOFC 研究会拉よび米国電気化学会, 講演 110 件。第 3 回 SOFC 国際シンポジウムは1993 年5月16〜22 日，ハワイで日米電気化学大会に扔い て開催される。主催：米国電気化学会高温材料部会, 共催：SOFC 研究会扰 びヨーロッパ共同体, 講演 110 件。

SOFC 関する研究発表㹥電気化学協会の春秋の大会, 電池討論会, 固体1 オニクス討論会などにかいて，SOFC・関連項目について，100件をはるかに越 える数の研究発表がなされている。また，情報交換・討論の場として設けられ た SOFC 研究会の会員数は 120 (個人 62 ，法人 62）を越え，年に 4 回開催され る定例研究集会の参加者は每回 100〜130名に及んている。記講演発表会上は 別に，研究開発状況の発表の場が必要になったことから，新たに研究発表会を 毎年開催寸ること纪した。第 1 回 SOFC 研究発表会は 1992 年 12 月 15,16 日の 両日, 科学技術館サイエンスホールにてSOFC 研究会の主催によって開催され た。講演 32 件。

(田川 博章)

\section{8.その他の懇談会}

上述した研究・技術愁談会は現在活動しているものであり，これまで発足し た研究・技術愁談会の中には，ある限られた期間だけ活動し目的達成の後に解 散したものや，尃門委員会へ移行したもの(「センサ研究留談会」から「化学せ ンサ研究会」へ(昭和 59 年)，「電解溶液の化学想談会」加ら「溶液化学委員会」 人 (昭和 55 年)，「ソーダ工業技術等談会」かららソーダ工業技術委員会」へ(昭 和 58 年), 「工業電解用電極材料技術懇談会」と「電解工学研究留談会」が「ソ 